www.nature.com/bmt

\title{
Corrigenda
}

\section{T-cell depletion improves outcome after autologous stem cell transplant in patients with systemic lupus erythematosus (SLE)}

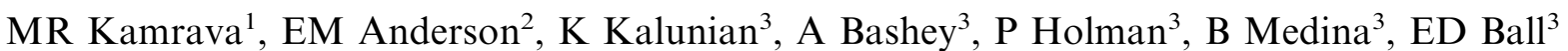
and E Carrier ${ }^{3}$

Bone Marrow Transplantation (2005) 35, 321. doi:10.1038/sj.bmt.1704825
The author A Bashey's name was published incorrectly; the correct version is shown above.

Correction to: Bone Marrow Transplantation (2005) 35,

205-206. doi:10.1038.sj.bmt.1704738

\section{Syndrome ' $\mathrm{X}$ ' in adult female recipients of bone marrow transplantation for haematological malignancies}

R Chatterjee, K Palla, HH McGarrigle, S Mackinnon and PD Kottaridis

Bone Marrow Transplantation (2005) 35, 321.

doi:10.1038/sj.bmt.1704837
The author S Mackinnon's name was published incorrectly; the correct version is shown above.

Correction to: Bone Marrow Transplantation (2005) 35,

209-210. doi:10.1038.sj.bmt.1704744

\section{Erratum}

\section{Disseminated tuberculosis following reduced-intensity cord blood transplantation for adult patients with hematologic diseases}

T Maeda, E Kusumi, M Kami, M Kawabata, A Le Pavoux, S Hara, A Chizuka, N Murashige, TE Tanimoto, T Matsumura, K Yuji, A Wake, S Miyakoshi, S Morinaga and S Taniguchi, for the Tokyo Stem Cell Transplant (SCT) Consortium

Bone Marrow Transplantation (2005) 35, 321.

doi:10.1038/sj.bmt.1704824
The author K Yuji's name was published incorrectly; the correct version is shown above.

Correction to: Bone Marrow Transplantation (2005) 35,

91-97. doi:10.1038/sj.bmt.1704740 